\title{
Childhood Vaccination in the Twenty-First Century: Parental Concerns and Challenges for Physicians
}

\author{
Srdja Janković \\ University Children's Hospital, Tiršova 10, 11000 Belgrade
}

Email: srdja.jankovic@udk.bg.ac.rs

\begin{abstract}
Summary
Vaccination is one of the most important methods of prevention of infectious disease, saving millions of lives worldwide and protecting people from potentially debilitating complications. It is therefore hailed as one of the greatest advances of science-based medicine of all times. Although repeatedly proven safe and effective, vaccination has been questioned and resented throughout its long history. Vaccine hesitancy and refusal are once again on the rise in this century, due to a complex interplay of numerous factors and circumstances. A decline in childhood vaccination rates has already resulted in resurgence of hitherto eliminated vaccinepreventable diseases in many countries, and is now perceived as a major public health threat. This decline is closely related to increasing spread of misinformation regarding vaccine safety and effectiveness, coupled with a growing anti-vaccine activism. This, among other issues, underscores the need to improve communication between healthcare workers and parents, as well as devise a more comprehensive approach to boosting vaccine confidence, where scientists, physicians, media and the general public all have important roles to play. In this paper, we discuss the phenomenology and causal structure of vaccine hesitancy and refusal, and briefly review some widespread vaccine-related questions of everyday practical importance.
\end{abstract}

Keywords: vaccination, child, vaccine hesitancy, public health 


\section{Introduction}

Vaccination is arguably the greatest triumph of science and science-based medicine. For more than two centuries, vaccines have been protecting millions of people from dangerous and deadly infectious diseases, one of which (smallpox) has been successfully eradicated (Simmons et al., 2015), while another (poliomyelitis) is now close to eradication (Merten, 2019). However, due to a complex interplay of factors, both vaccination rates and vaccine coverage are currently in considerable decline in many countries: vaccine hesitancy and refusal are on the rise (Dubé et al., 2013). In Serbia, some degree of vaccine hesitancy was recently self-reported by approximately $19 \%$ of parents who responded to a poll performed by Ipsos on behalf of UNICEF; however, people who profess firm anti-vaccine attitudes amounted to no more than $1 \%$ of respondents (UNICEF, 2017). The return of measles, a hitherto eliminated disease, claimed fifteen human lives in the season 2017/2018 (Institute of Public Health of Serbia, 2019). Decline of immunization rates and resurgence of vaccine-preventable diseases have been reported accross Europe, though with considerable variation among countries (Rechel et al., 2018). This phenomenon is partly caused by increasing activity of individuals and groups advocating anti-vaccine attitudes, i. e., questioning safety and effectiveness of vaccines, scientific evidence, and often also motives and intentions of professionals involved in vaccination (Poland \& Jacobson, 2012; Janković, 2014). Coupled with the advent of social networks and other means of rapid sharing of information, and unfortunately also misinformation (Stahl et al., 2016), this trend is increasingly wreaking confusion among parents and caregivers. In this paper, we discuss the phenomenology and causes of vaccine hesitancy and refusal, and briefly review some of the issues most frequently raised by parents or caregivers as cause of their concern.

\section{History of Vaccination: A Brief Reminder}

The fact that some infectious diseases endow their survivors with lifelong protective immunity was well known since antiquity, as testified by the account of the „plague of Athens” (430 BC) written by Thucidydes (Littman, 2009). The great Greek historian noted that people who recovered from this epidemic disease, caused by an unknown pathogen, were subsequently protected from contracting the same disease again, and thus were safe to tend the sick and dying fellow citizens. Similar knowledge was exploited for centuries in Chinese traditional medicine, where dried powder taken from the lesions of people who recovered from smallpox used to be inhaled or scratched into the skin of healthy persons, protecting them from the disease, albeit at the cost of usually moderate, but sometimes life-threatening, and even fatal adverse reactions. The practice later became widespread in Asia. It was brought to Europe by Lady Mary Wortley-Montagu (wife of the British ambassador to Istanbul), where it became known 
as variolation (Stone \& Stone, 2002). Variolaton offered life-saving protection against smallpox, a disease with a mortality rate of about $30 \%$ in European populations at the time, that also often caused permanent blindness and disfiguration of survivors. At the turn of the nineteenth century, variolation was replaced by Edward Jenner's first vaccine. As widely known, the name was derived from cowpox, or vaccinia, a mild disease in humans, mostly affecting milkmaids, who frequently came into contact with infected cattle. Smallpox and vaccinia are caused by closely related viruses that share many antigens and thus elicit cross-reactive immunity (Rusnock, 2016). Although initially greeted with skepticism, some moral criticism, and even derision, vaccination soon proved to be the most effective means of protection against infectious disease. In the nineteenth century, Louis Pasteur successfully developed a vaccine against rabies, an invariably fatal disease, as well as a (veterinary) vaccine against anthrax (D'Amelio et al., 2016). With the advance of immunology and ever-improving undestanding of underlying principles of acquired immunity and immune memory, many new vaccines have been (and are still being) developed. Even by most conservative assessments, the number of lives saved by vaccines worldwide is on the order of millions. The accumulation of scientific knowledge has also enabled vast improvements in vaccine safety and effectiveness over time, as well as the design of many new types of vaccines. Today this can be achieved using modern tools of molecular biology, vastly expanding the realm of possibilities (Plotkin, 2014). This includes emerging technologies, such as gene libraries or fully synthetic molecular constructs.

\section{Vaccine-Preventable Diseases}

Vaccination has so far eliminated or drastically reduced the risk of many diseases that, historically, exerted a terrible toll on humanity (Weil, 2016). Apart from the above example of smallpox, children (and adults) in most parts of the world are now safe from diphteria, tetanus, and poliomyelitis (Vitek, 2006; Roush et al., 2007; Merten, 2019). The incidence of whooping cough, a bacterial infection that is often fatal in newborns and infants, has also been significantly curbed, although there is some resurgence due to a number of factors (insufficient lifelong immunity, possible development of resistance, decrease in vaccine uptake; please see Domenech de Cellés et al., 2018). Immunization against Mycobacterium tuberculosis, although only modestly effective in preventing infection, has shown near-total effectiveness against most severe and life-threatening forms of the disease (milliary tuberculosis, tuberculous meningitis; Trunz et al., 2006; Mangtani et al., 2014). Recent introduction of conjugate vaccines against Hemophilus influenzae type B, Pneumococcus, and (in some countries) Neisseria meningitidis caused a considerable drop in the incidence of complications caused by these pathogens, endowed by a protective polysaccharide capsule as a factor of their virulence (Vella \& Pace, 2015; Rappuoli, 2018). Measles, mumps and rubella have been eliminated in many countries (including Serbia), but have been ,brought back” from the brink of 
eradication by the infamous autism scare (Porter \& Goldfarb, 2019; see also below). Another common childhood viral disorder accompanied by rash and fever, chickenpox, has been suppressed by vaccination in many countries, which is now recommended in Serbia as well. Rates of hepatitis B are steadily declining in countries that adopted recommended or compulsory vaccination (Nelson et al., 2016), while the vaccination against human papillomavirus (HPV), causative agent of cervical carcinoma and a number of other tumors in both sexes, resulted in significant reduction in precancerous lesions caused by vaccine-preventable oncogenic strains of this DNA virus; the latent period from infection to malignancy is rather long, but countries that had been among the first to adopt HPV vaccine on a large scale, such as Australia, are already registering a drop in the incidence of HPV-related cancer, raising hopes of potential global elimination of these types of cancer towards the end of next decade (Canfell, 2019). Cervical cancer rates are also declining in many countries that introduced HPV vaccination more recently, notably Finland, which is partly due to highly efficient screening programs, highlighting the synergy between vaccination and other methods of disease prevention. Many more vaccines are used against infectious diseases in specific contexts or areas, such as vaccines against rabies, yellow fever, dengue, or, most recently, ebola. There are also many vaccines that are currently in the process of development.

\section{Vaccine Hesitancy and Vaccine Refusal}

It may seem as a bit of a paradox that vaccine hesitancy and refusal are increasing right in the face of incontrovertible successes of vaccination. However, apprehensive, reluctant, and potentially negative attitudes of patients and caregivers toward vaccination spring from a complex mixture of motives (Meyer \& Reiter, 2004): fear of the unknown (or poorly understood); rarity of encounters with vaccine-preventable diseases (where vaccination is, in a way, ,victim of its own success”); philosophical views on „natural” vs. ,artificial”, associated with various misconceptions regarding health and disease; growing mistrust of the so-called „official” (or „Western”) medicine and science; view that healthcare providers could be corrupt or subject to their own biases and vested interests, not necessarily matching the interests of patients and/or public health; wide exposure to contradictory claims (and, indeed, viral misinformation) regarding vaccine safety and effectiveness, with insufficient level of rationality and critical thinking. A model developed by the SAGE Working Group clusters many factors contributing to vaccine hesitancy into three overlapping areas: complacency, confidence and convenience (MacDonald et al., 2015). All three clusters of factors are strongly connected with emotional responses. Unsurprisingly, studies have demonstrated a consistent link between appeal to emotions and vaccine hesitancy (Tomljenović et al., 2019). Vaccine hesitancy is also associated with viral spread of misinformation (Yiannakoulias et al., 2019; Broadbent, 2019), particularly relating to 
media coverage of high-profile court cases centered on harm allegedly caused by vaccines (Carrieri et al., 2019). Interestingly, mistrust and avoidance of vaccines appears to be generally more prevalent in areas with higher level of socioeconomic advantage, and in persons with higher level of education, which has been dubbed ,the privilege paradox" (Bryden et al., 2019).

Analytical studies have demonstrated that complacency (not perceiving the risk of infectious disease as important), constraints (systemic and psychological obstacles), calculation (such as extensive information searching), and some aspects pertaining to collective responsibility (willingness to protect others) all play important roles in explaining vaccination behavior (Betsch et al., 2018). A recent Cochrane meta-analysis of ten studies found that face-to-face interventions for educating parents about early childhood vaccination may improve children's vaccination status to some degree. Less encouragingly, however, the effect has mainly been observed in settings of isufficient awareness or understanding of vaccine issues, while the impact of intervention is far less clear when vaccine hesitancy or refusal is thought to be the main barrier (Kaufman et al., 2018). In any case, the approach to tackling vaccine hesitancy needs to be, above all, child/parent-centered and based on general education and communication skills (MacDonald \& Dubé, 2018). Importantly, for most parents, including those that are vaccine-hesitant, physicians (and other healthcare workers) still constitute the principal - and most trusted - source of information regarding vaccines (Kennedy et al., 2011; Mergler et al., 2013; Kundi et al., 2015). Most parents who voice concerns about safety of vaccination actually seek reassurance rather than confrontation. Thus pediatricians, and other health professionals, are typically presented with a golden opportunity to allay any unwarranted (or overmagnified) fears, regain the parents' confidence and positively influence their decision. This once again highlights the importance of communication skills (Nayar et al., 2019; Possenti et al., 2019). In fact, parents usually respond favorably to clear, concise, and honest messages of physicians, and like to have their questions answered as plainly as possible (Healy \& Pickering, 2011), which, in turn, points to the need for good knowledge base and personal integrity of helthcare professionals, as well as for systematically offering these professionals adequate training and support.

Since both the roots and the consequences of the problem of vaccine hesitancy concern society as a whole, apart from physicians and other healthcare workers, many other instances and institutions need to contribute to improving outcomes. Some good examples of social mobilization as a key factor in securing vaccine acceptance have been detailed by Jalloh and coworkers (Jalloh et al., 2019). Some studies provided evidence that the internet, including social networks, can be used creatively to enhance the message about the importance of vaccines for public health, contributing to positive parents' attitudes (Daley et al., 2018), although this carries some risk of increased 
polarization and enhanced ,echochamber effect”, or even backfire. It is crucial to keep in mind at all times that true opponents of vaccination comprise only a minority of the population, while the vast majority of those parents/caregivers who hesitate, postpone, or deny some or all vaccines to their children state that they are not against vaccination in principle, but refer to safety concerns and other issues broadly related to (rather skewed) public perception of vaccines. In particular, risks of serious adverse events following vaccination, although extremely small in terms of frequency, tend to receive disproportionately more public attention compared to risks of vaccine-preventable diseases, since the reduction or elimination of the latter, and their consequent absence (or near-absence) from most or all communities, often gets taken for granted, in accordance with well-known findings of cognitive psychology that people typically fail to consider what they do not see. Naturally, this situation tends to change in times of epidemics. For instance, in our experience, during the epidemic of measles that recently struck Serbia (together with several other countries), some parents who had previously rejected the measles, mumps and rubella (MMR) vaccine, mostly out of ill-founded fear of autism-spectrum disorders (please see below), rapidly changed their minds and accepted their children to be vaccinated; indeed, quite a few of them even actively requested from their pediatricians to immunize the child as soon as possible.

There is one more ethical and practical dimension to vaccine hesitancy: apart from the protection afforded to the individual, an important aspect of vaccination is attached to collective immunity - prevention of spread of infection once a certain threshold of immunization coverage is reached in a given population (the exact threshold level depends on how contagious the disease in question is). Collective immunity is crucial for keeping infectious disease away, and thus protecting people who cannot be vaccinated due to medical contraindications, as well as babies and small childen not yet vaccinated (depending on the specific vaccine timetable recommendations). Compromising collective immunity by faltering vaccine acceptance can therefore endanger many more lives. It is very important to keep in mind that collective immunity operates at the community level: even if coverage is, on the average, adequate nationwide, ,pockets” of poor coverage may (and, indeed, do) give rise to local epidemics (Giubilini et al., 2018).

\section{Vaccine Safety: Global Evidence Base}

Since vaccines have been, with constant improvement, used for a very long time, overwhelming evidence has accumulated as to their safety. Even though no medical agent or procedure can be absolutely devoid of risk, severe adverse effects of vaccination are extremely rare (WHO, 2012). There is, however, still some speculation about the possibility that vaccines may trigger a wide range of disorders, including allergic and autoimmune diseases. While this possibility must never be taken lightly, 
comprehensive analyses confirmed that, for most disorders, there is no difference in incidence between vaccinated and unvaccinated persons. However, one may easily get a very different picture by reading raw data from passive surveillance registries such as VAERS (Vaccine Adverse Events Reporting System), or reports of individual patients or patient series. Crucially, such reports, although very important as data sources for further analysis, require additional scrutiny in order to determine the existence of a causal connection (or lack thereof); in other words, without proper comparison, and adequate control for relevant confounding factors, there is no way to differentiate a mere temporal connection (i. e., a coincidence) from a causal relation. For instance, one study found that probable causality could be established in less than a quarter of investigated VAERS reports, and these were dominated by mild reactions, allergic reactions and symptoms specifically associated with vaccine administered (Loughlin, 2012).

As with any agents, allergic (and, more often, pseudoallergic) reactions to vaccines are certainly possible (Barbaud et al., 2013). Indeed, they probably constitute the best documented category of potentially severe, and even life-threatening adverse effects of vaccination. However, such occurrences are still extremely rare and, although presently unpredictable, generally are amenable to treatment. Also, since vaccines are designed to trigger an immune response accompanied by a (minimal) inflammatory reaction needed to elicit the mechanisms ultimately leading to immune memory, there is a certain potential of triggering an autoimmune reaction in persons with unusually (idiosyncratically) high susceptibility. However, proven autoimmune adverse reactions to vaccination are quite rare and mostly limited to a few clinical entities, such as Guillain-Barré syndrome, autoimmune thrombocytopenia and narcolepsy. (For a review of documented, putative and speculative instances of autoimmunity associated with vaccination, please see Janković, 2017.)

Some of the most prevalent concerns of parents regarding vaccination are discussed below.

\section{Do Vaccines Contain „Toxins”?}

One of common concerns stated by parents (and widely reflected in the media and general public) is that vaccines contain many toxic substances, potentially harmful to children. As a rule, these concerns are tied to „,bad reputation” of certain substances (for example, their known toxic effects in other contexts), but with more or less complete disregard of key principles of toxicology, including, first and foremost, the fact that for any toxic effect there is a threshold of dose and exposure. In this light, even though some components of vaccines indeed have the potential to be toxic, they are not actually toxic, since their concentration and total amount in vaccines are very strictly regulated, and never allowed to approach the toxicity threshold. Indeed, there is usually 
a safety factor of at least an order of magnitude between the acceptable level of exposure and the lowest exposure that could entail toxicity. The key insight that no discussion of toxicity can be meaningful without explicitely considering dose is traditionally credited to Philippus Aureolus Theophrastus Bombastus von Hohenheim, a fifteenth/sixteenth century Swiss alchemist, astrologer, physician and proto-scientist, better known as Paracelsus.

As an example, aluminium is used in many vaccines, usually in the form of hydroxide, as an adjuvant - component intended to stimulate the immune response to a certain degree, in order to elicit long-term immune memory of target antigens. Aluminium is, as pointed out ad nauseam by vaccination opponents, a known neurotoxin. However, even though exact amounts of aluminium-containing adjuvants per vaccine dose had initially been defined empirically, the quantity of aluminium present in any vaccine does not exceed the established threshold of toxicity (Ameratunga et al., 2017; Principi \& Esposito, 2018). A single dose of vaccine against hepatitis $\mathrm{B}$, for instance, contains $0.5 \mathrm{mg}$ of aluminium (in the form of hydroxide). This quantity is equivalent to the amount that is usually ingested with food (including mother's milk) over a brief period of time, since aluminium is an abundant metal in the composition of Earth's crust and therefore present in our living environment (please see Corkins, 2019 and references therein). Correspondingly, aluminium levels in biological samples of vaccinated persons have not been found to differ from those in unvaccinated persons, while rare vaccine adverse effects that had been attributed to aluminium-based adjuvants, such as macrophagic myofasciitis, do not appear to be caused by aluminium toxicity per se (Goullé \& Grangeot-Keros, 2019). In brief, while ongoing research directed at further optimization of vaccine adjuvants, including the design of new compounds and formulations guided by the accumulating knowledge of immunological mechanisms is unquestionably warranted, aluminium-based adjuvants remain the golden standard for such research (HogenEsch et al., 2018).

For a second example, many vaccines contain formaldehyde, known to be toxic in a sufficient dose. However, all vaccines a child typically receives during childhood combined contain no more than $1 \mathrm{mg}$ of formaldehyde (which is, furthermore, quickly degraded and does not accumulate); this is much lower than the amount normally present in the human body at any given time, or indeed the amount present in many common food items, such as bananas, apples, pears or apricots, as well as many vegetables, not to mention shitake mushrooms, containing considerable, yet still harmless amounts. It is estimated that $1 \mathrm{~kg}$ of bananas, on the average, contains $16.3 \mathrm{mg}$ of formaldehyde, while $1 \mathrm{~kg}$ of apricots contains about $9.5 \mathrm{mg}$ (Centre for Food Safety, 2019). An analysis performed in USA by the Center for Biologics Evaluation and Research revealed that the amount of formaldehyde received from a single dose of a typical vaccine does not exceed $1 \%$ of the amount of formaldehyde normally present in 
human body, and that this formaldehyde is metabolically degraded within 30 minutes (Mitkus et al., 2013). There is, therefore, no risk of toxic effects.

On the other hand, concerns about ,toxins" present in vaccines are sometimes merely a consequence of poor general understanding of chemistry. The most salient example is the claim that vaccines contain hydrochloric acid: this compound is actually added to vaccines just in order to adjust their final $\mathrm{pH}$ to neutral or physiological value. Hydrochloric acid itself is no longer present as such in the vaccine at time of its application, since it gets neutralized by other, slightly alcaline vaccine components; indeed, without the addition of acid to adjust the $\mathrm{pH}$, vaccine would not be usable - for then it would indeed be toxic! To conclude, fears of „toxins” in vaccines are misplaced. No vaccine can be licensed without undergoing a comprehensive process of verification that none of its components exhibit toxicity at doses or levels of exposure involved (Gorski, 2008).

\section{Are Vaccines Safe to Combine?}

A common reason of stated concern is the notion that children are exposed to ,too many" vaccine antigens. However, the immune system of every person daily encounters millions of antigens ever since (and even before) birth, with antigens associated with pathogenic organisms comprising only a tiny part of this number. Adaptive immune response has developed through evolution in order to provide a highly specific immune response to every individual antigen. More importantly, since different clones of lymphocytes respond to different antigens, a theoretically unlimited number of such responses may (and does) occur simultaneously, without placing any undue burden on the resources of the immune system. There is also ample evidence that combined vaccines, which have already been used for many decades, never produced any signs of „immune overload” (Offit et al., 2002; Iqbal et al., 2013). In addition, more recent vaccine designs are generally more purified. Therefore modern vaccines tend to contain an ever smaller number of antigens, thus reducing the overall antigenic burden associated with vaccines awaiting current and future generations, compared with the number of vaccine antigens children encountered in the past.

\section{Can Vaccines Somehow „Weaken” the Immune System?}

Many parents will ask their healthcare providers whether vaccinated children will have a less well developed immune systems, due to reduced stimulation by infections. This concern is wholly unfounded, although it is now known that exposure to a wide range of microorganisms, including some that may be pathogenic under some circumstances, is indeed beneficial, and even protects from development of allergies and autoimmune disorders (according to the well-known „hygiene hypothesis", increasingly supported by evidence). A crucial point is, however, that pathogens 
targeted (and hopefully eliminated) by vaccination are generally neither part of healthy microbiome nor beneficial stimulants of the immune system. Protection from such agents is therefore no loss but a great gain for a person's health, as testified by many studies that found no increase, and even a slight decrease, in the incidence of allergic conditions in children who received vaccines. Also of note, immune responses of vaccinated children to unrelated pathogens have not been found to be reduced in any way (Nicoli \& Appay, 2017).

\section{Vaccine Concerns: Some Common Examples}

\section{Autism Spectrum Disorders}

Probably the most (in)famous vaccine-relared concern in most parts of the world is the association between MMR vaccine and autism spectrum disorders (ASD). The existence of a link between the two, hypothesized in the 1998 Lancet article by Andrew Wakefield, has been extensively researched during the last two decades, and no such link has been found. The conclusion that the association is merely temporal (in other words, spurious) is attested by many large-scale, methodologically rigorous, independent studies. It is true that the first signs of ASD are very often noticed at the age when children are due to receive the MMR vaccine; however, children immunized with MMR (or any other vaccine) do not develop ASD more often than children that were not vaccinated. Meanwhile, the original study linking MMR vaccine with ASD has been retracted due to both methodological and ethical flaws (see, for example, Taylor et al., 2014; Jain et al., 2015; Hviid et al., 2019; for a comprehensive review, please see DeStefano \& Shimabukuro, 2019).

Another consequence of the vaccines-ASD story is the reluctance of many pediatricians to vaccinate children with perceived developmental delay of any kind (or a supposed risk thereof), with the tendency to postpone vaccination for months, or even years, ,,until the child has safely learned to walk and talk". This is not only scientifically unfounded, but also brings children under risk of infection, which may cause serious complications. Ironically, this delay is particularly likely to occur in children with neurological conditions that also make them especially vulnerable to infection. And since diseases that had been eliminated by MMR vaccine have now returned to many countries due to falling vaccination rates, some of these vulnerable children are now at risk of contracting these diseases, notably measles, which carries a considerable complication rate even in healthy children, and is all the more dangerous in those with a weakened immune system, neurodevelopmental disorders, or both. Because of all this, it is imperative that all healthcare workers be armed with facts and well-prepared to offer concerned parents a thorough explanation and reassurance (with consultation of a pediatric neurologist and immunologist where necessary). 


\section{Egg Allergy}

Some vaccines, such as MMR, are manufactured using viruses grown in chick embryos. For this reason, initial recommendations on vaccination included special precautions for persons with known or suspected egg protein allergies. However, it was found that there is no cross-reactivity with antigen epitopes that may potentially remain in the vaccine after purification, and that allergic reactions to MMR (or any other vaccine), including anaphylactic shock, are not more frequent in persons allergic to eggs than in the general population (Andersen \& Jørgensen, 2013; Sánchez et al., 2018; Kara Elitok et al., 2019; Czajka et al., 2019). For this reason, witholding vaccination from such persons is no longer recommended, and should be discouraged. Previous anaphylactic reaction to vaccine (not egg proteins) is still a contraindication, although it is possible to test immediate sensitivity to vaccine itself before applying the latter, as well as to vaccinate in hospital settings with appropriate precautions (Tuncel et al., 2017).

\section{Immune thrombocytopenia}

Immune thrombocytopenia (ITP) is a known rare autoimmune adverse effect of some vaccines, notably MMR, whereupon it occurs with an incidence of 1:40,000 to 1:35,000 doses. However, since infections (including measles) are most often (in 80$90 \%$ of cases) the trigger of ITP, vaccine-triggered ITP comprises only about $10 \%$ of all childhood ITP. In addition, vaccine-triggered ITP is most often $(>90 \%)$ self-limited and resolves without any harm to the child. The risk of ITP ensuing after vaccination is therefore not considered a reason not to vaccinate, since the child would be exposed to a much greater risk of the same condition if left unvaccinated. Even in children who previously suffered an episode of acute ITP, including vaccine-triggered ITP, MMR (or any other) vaccine is not strictly contraindicated. Children with chronic ITP can (and should) also be vaccinated, albeit with the precaution of choosing the time when disease activity is low and platelet number reasonably recovered (O'Leary et al., 2012; Cecinati et al., 2013).

\section{Concluding Remarks}

Scientists designing and testing vaccines, doctors and nurses administering them, media reporting on the whole process, and the general public, including traditional decision-makers, constitute the four corners of a ,communication quadrangle”. Stable and effective communication conductive to good outcomes requires all four corners to be stable. In other words, overcoming the threat of vaccine hesitancy and protecting vulnerable lives will require all parts of society to play their roles - at community, national, regional and global levels. Only then may we hope to benefit from the full protective potential of the most powerful tool of medical science. 


\section{Acknowledgments}

The author received support from the Ministry of Education, Science and Technological Development No. 41004. The author declares no conflict of interest.

\section{References}

1. Ameratunga R, Gillis D, Gold M, Linneberg A, Elwood JM. Evidence refuting the existence of autoimmune/autoinflammatory syndrome induced by adjuvants (ASIA). J Allergy Clin Immunol Pract. 2017; 5(6):1551-1555.

2. Andersen DV, Jørgensen IM. MMR vaccination of children with egg allergy is safe. Dan Med J. 2013; 60(2):A4573.

3. Barbaud A, Deschildre A, Waton J, Raison-Peyron N, Tréchot P. Hypersensitivity and vaccines: an update. Eur J Dermatol. 2013; 23(2):135-41.

4. Betsch C, Schmid P, Heinemeier D, Korn L, Holtmann C, Böhm R. Beyond confidence: development of a measure assessing the $5 \mathrm{C}$ psychological antecedents of vaccination. PLoS One 2018; 13(12): e0208601.

5. Broadbent JJ. Vaccine hesitancy: misinformation on social media. BMJ 2019; 366: I4457.

6. Bryden GM, Browne M, Rockloff M, Unsworth C. The privilege paradox: geographic areas with highest socio-economic advantage have the lowest rates of vaccination. Vaccine 2019; 37(32):4525-32.

7. Canfell K. Towards the global elimination of cervical cancer. Papillomavirus Res. 2019 (in press); DOI: 10.1016/j.pvr.2019.100170.

8. Carrieri V, Madio L, Principe F. Vaccine hesitancy and (fake) news: quasi-experimental evidence from Italy. Health Econ. 2019 (in press); doi: 10.1002/hec.3937.

9. Cecinati V, Principi N, Brescia L, Giordano P, Esposito S. Vaccine administration and the development of immune thrombocytopenic purpura in children. Hum Vaccine Immunother. 2013; 9(5):1158-62.

10. Centre for Food Safety. The Government of Hong Kong Special Administrative Region. Food Additives. Available at:

https:/www.cfs.gov.hk/english/programme/programme_rafs/programme_rafs_fa_02_09.html; last accessed on October $14^{\text {th }}, 2019$.

11. Corkins MR; Committee on Nutrition. Aluminum effects in infants and children. Pediatrics 2019; 144(6): e20193148. 
12. Czajka H, Czajka S, Dylag KA, Borek E, Kuchar E. Vaccination against measles, mumps, and rubella in the light of current epidemic threats: unjustified postponement. Adv Exp Med Biol. 2019; 1153:101-7.

13. D'Amelio E, Salemi S, D'Amelio R. Anti-infectious human vaccination in historical perspective. Int Rev Immunol. 2016; 35(3):260-90.

14. DeStefano F, Shimabukuro TT. The MMR vaccine and autism. Annu Rev Virol. 2019; 6(1):585600.

15. Domenech de Cellès M, Magpantay FMG, King AA, Rohani P. The impact of past vaccination coverage and immunity on pertussis resurgence. Sci Transl Med. 2018; 10(434): pii: eaaj1748.

16. Dubé E, Laberge C, Guay M, Bramadat P, Roy R, Bettinger J. Vaccine hesitancy: an overview. Hum Vaccin Immunother. 2013; 9(8):1763-73.

17. Giubilini A, Douglas T, Savulescu J. The moral obligation to be vaccinated: utilitarianism, contractualism, and collective easy rescue. Med Health Care Philos. 2018; 21(4):547-560.

18. Gorski D. Toxic Myths About Vaccines. Science-Based Medicine 2008; available at: https://sciencebasedmedicine.org/toxic-myths-about-vaccines/; last accessed: October $15^{\text {th }}, 2019$.

19. Goullé JP, Grangeot-Keros L. Aluminum and vaccines: current state of knowledge. Med Mal Infect. 2019 [in press]; S0399-077X(18)30844-8.

20. Healy CM, Pickering LK. How to communicate with vaccine-hesitant parents. Pediatrics 2011; 127 Suppl 1:S127-33.

21. HogenEsch H, O'Hagan DT, Fox CB. Optimizing the utilization of aluminum adjuvants in vaccines: you might just get what you want. NPJ Vaccines 2018 [in press]; DOI: 10.1038/s41541018-0089-x.

22. Hviid A, Hansen JV, Frisch M, Melbye M. Measles, Mumps, Rubella vaccination and autism: a national cohort study. Ann Intern Med. 2019; 170(8):513-520.

23. Institute of Public Health of Serbia „Dr. Milan Jovanović Batut”: Aktuelna epidemiološka situacija malih boginja (morbila) u Republici Srbiji. Available at: http://www.batut.org.rs/index.php?content=1629; last accessed on October 14 ${ }^{\text {th }}, 2019$.

24. Iqbal S, Barlie JP, Thompson WW, DeStefano F. Number of antigens in early childhood vaccines and neuropsychological outcomes at age 7-10 years. Pharmacoepidemiol Drug Saf. 2013; 22(12):1263-70.

25. Jain A, Marshall J, Buikema A, Bancroft T, Kelly JP, Newschaffer CJ. Autism occurrence by MMR vaccine status among US children with older siblings with and without autism. JAMA 2015; 313(15): 1534-40.

26. Jalloh MF, Wilhelm E, Abad N, Prybylski D. Mobilize to vaccinate: Lessons learned from social mobilization for immunization in low and middle-income countries. Hum Vaccin Immunother. 2019 (in press); DOI: 10.1080/21645515.2019.1661206.

27. Janković S. Anti-vakcinalni pokreti i naučna medicina. Biomedicinska Istraživanja 2014; 5(1):5965.

28. Janković S. Vaccination and autoimmune phenomena. Central Eur J Paed. 2017; 13(1): 12-23. 
29. Kara Elitok G, Celikboya E, Bulbul L, Kaya A, Toraman T, Bulbul A, et al. Does food allergy require any change in measles-mumps-rubella vaccination? Indian J Pediatr. 2019; 86(10):915-20.

30. Kaufman J, Ryan R, Walsh L, Horey D, Leask J, Robinson P, et al. Face-to-face interventions for informing or educating parents about early childhood vaccination. Cochrane Database Syst Rev. 2018; 5: CD010038.

31. Kennedy A, Basket M, Sheedy K. Vaccine attitudes, concerns, and information sources reported by parents of young children: results from the 2009 HealthStyles survey. Pediatrics 2011;127(Suppl 1); S92-99.

32. Kundi M, Obermeier P, Helfert S, Oubari H, Fitzinger S, Yun JA, et al. The impact of the parentphysician relationship on parental vaccine safety perceptions. Curr Drug Saf. 2015; 10(1):16-22.

33. Littman RJ. The plague of Athens: epidemiology and paleopathology. M Sinai J Med. 2009; 76(5):456-67.

34. Loughlin AM, Marchant CD, Adams W, Barnett E, Baxter R, Black S, et al. Causality assessment of adverse events reported to the Vaccine Adverse Events Reporting System (VAERS). Vaccine 2012; 30(50):7253-9.

35. MacDonald NE; SAGE Working Group on Vaccine Hesitancy. Vaccine hesitancy: Definition, scope and determinants. Vaccine 2015; 33(34):4161-4.

36. MacDonald NE, Dubé E. Addressing vaccine hesitancy in immunization programs, clinics and practices. Paediatr Child Health 2018; 23(8):559-60.

37. Mangtani P, Abubakar I, Ariti C, Beynon R, Pimpin L, Fine PE, Rodriguez LC, et al. Protection by BCG vaccine against tuberculosis: a systematic review of randomized controlled trials. Clin Infect Dis. 2014; 58(4):470-80.

38. Mergler MJ, Omer SB, Pan WK, Navar-Boggan AM, Orenstein W, Marcuse EK, et al. Association of vaccine-related attitudes and beliefs between parents and health care providers. Vaccine 2013; 31(41):4591-5.

39. Merten M. Polio: getting ready for the day after eradication. BMJ 2019; 366:I5235.

40. Meyer C, Reiter S. Impfgegner und impfskeptiker. Bundesgesundheitsblat Gesundheitsforschung Gesundheitsschutz 2004; 47:1182-88.

41. Mitkus RJ, Hess MA, Schwartz SL. Pharmacokinetic modelling as an approach to assessing the safety of residual formaldehyde in infant vaccines. Vaccine 2013; 31(25):2738-43.

42. Nayar RK, Nair AT, Shaffi M, Swarnam K, Kumar A, Abraham M, et al. Methods to overcome vaccine hesitancy. Lancet 2019; 393(1077): 1203-4.

43. Nelson NP, Easterbrook PJ, McMahon BJ. Epidemiology of hepatitis B virus infection and impact of vaccination on disease. 2016; 20(4):607-628.

44. Nicoli F, Appay V. Immunological considerations regarding parental concerns on pediatric immunizations. Vaccine 2017; 25(23):3012-9.

45. Offit PA, Quarles J, Gerber MA, Hackett CJ, Marcuse EK, Kollman TR, et al. Addressing parents' concerns: do multiple vaccines overwhelm or weaken the infant's immune system? Pediatrics 2002; 109:124-129. 
46. O’Leary ST, Glanz JM, McClure DL, Akhtar A, Daley MF, Nakasato C. The risk of immune thrombocytopenic purpura after vaccination in children and adolescents. Pediatrics 2012; 129(2):248-55.

47. Plotkin S. History of vaccination. Proc Natl Acad Sci USA 2014; 111(34):12283-7.

48. Poland GA, Jacobson RM. The clinician's guide to the antivaccinationists' galaxy. Human Immunol. 2012; 73:859-66.

49. Porter A, Goldfarb J. Measles: a dangerous vaccine-preventable disease returns. Cleve Clin J Med. 2019; 86(6): 393-8.

50. Possenti V, Luzi AM, Colucci A, De Mei B. Communication and basic health counselling skills to tackle vaccine hesitancy. Ann Ist Super Sanita 2019; 55(2):195-199.

51. Principi N, Esposito S. Aluminium in vaccines: Does it create a safety problem? Vaccine 2018; 36(39):5825-5831.

52. Rappuoli R. Glycoconjugate vaccines: principles and mechanisms. Sci Transl Med. 2018; 10(456): pii: eaat 4615

53. Rechel B, Richardson E, McKee M (Eds). The organization and delivery of vaccination services in the European Union. Prepared for the European Commission. European Observatory on Health Systems and Policies 2018. Available at:

https://ec.europa.eu/health/sites/health/files/vaccination/docs/2018_vaccine_services_en.pdf; last accessed on October $15^{\text {th }}, 2019$.

54. Roush SW, Murphy TV; Vaccine-Preventable Disease Table Working Group. Historical comparisons of morbidify and mortality for vaccine-preventable diseases in the United States. JAMA 2007; 298(18):2155-63.

55. Rusnock AA. Historical context and the roots of Jenner's discovery. Hum Vaccin Immunother 2016; 12(8):2025-28.

56. Sánchez J, Ramírez R, Cardona R. The frequency of allergic reactions to the triple viral vaccine in 94 patients with egg allergy. Biomedica 2018; 38(4):514-520.

57. Simmons BJ, Falto-Aizpurua LA, Griffith RD, Nouri K. JAMA Dermatol. 2015; 151(5):521.

58. Stahl JP, Cohen R, Denis F, Gaudelus J, Martinot A, Lery T, et al. The impact of the web and social networks on vaccination. New challenges and opportunities offered to fight against vaccine hesitancy. Med Mal Infect. 2016; 46(3):117-22.

59. Stone AF, Stone WD. Lady Mary Wortley Montagu: medical and religious controversy following her introduction of smallpox inoculation. J Med Biogr. 2002; 10(4):232-6.

60. Taylor LE, Swerdfeger AL, Eslick GD. Vaccines are not associated with autism: an evidence-based meta-analysis of case-control and cohort studies. Vaccine 2014; 32(29):3623-9.

61. Tomljenović H, Bubić A, Erceg N. It just doesn't feel right - the relevance of emotions and intuition for parental vaccine conspiracy beliefs and vaccination uptake. Psychol Health 2019 (in press); DOI: 10.1080/08870446.2019.1673894.

62. Trunz BB, Fine P, Dye C. Effect of BCG vaccination on childhood tuberculous meningitis and milliary tuberculosis worldwide: a meta-analysis and assessment of cost-effectiveness. Lancet 2006; 367(9517):1173-80. 
63. Tuncel T, Sancakli O, Ozdogru E. Successful administration of measles-rubella-mumps vaccine by graded challenge in a case with anaphylaxis after prior vaccination. Arch Argent Pediatr. 2017; 115(2):e89-e91.

64. UNICEF. Knowledge, attitudes and practices in relation to immunisation of children in Serbia. UNICEF 2017. Available at: https://www.unicef.org/serbia/sites/unicef.org.serbia/files/201812/Knowledge_Attitudes_Practices_Immunisation.pdf; last accessed: October 11 $11^{\text {th }}, 2019$.

65. Vella M, Pace D. Glycoconjugate vaccines: an update. Expert Opin Biol Ther. 2015; 15(4):529-46.

66. Vitek CR. Diphteria. Curr Top Microbiol Immunol. 2006; 304:71-94.

67. Weil AR. Eliminating vaccine-preventable diseases around the world. Health Aff. (Millwood) 2016; 35(2):190-4.

68. World Health Organization. Global Vaccine Safety Blueprint. 2012; available at: https://apps.who.int/iris/bitstream/handle/10665/70919/WHO_IVB_12.07_eng.pdf;jsessionid=2F0 AE6700D9600340B84C4D0172D434D? sequence $=1$; last accessed on October 15 ${ }^{\text {th }}, 2019$.

69. Yiannakoulias N, Slavik CE, Chase M. Expressions of pro- and anti-vaccine sentiment on You Tube. Vaccine 2019; 37(15):2057-64. 


\title{
Vakcinacija dece $u$ dvadeset prvom veku: nedoumice za roditelje i izazovi za lekare
}

\author{
Srđa Janković \\ Univerzitetska Dečija klinika, Tiršova 10, 11000 Beograd, Srbija
}

Email: srdja.jankovic@udk.bg.ac.rs

\section{Kratak sadržaj}

Vakcinacija je jedna od najznačajnijih metoda prevencije zaraznih bolesti, čuvajući na milione života u celom svetu i pružajući zaštitu od potencijalno onesposobljavajućih komplikacija. Stoga se vakcinacija smatra jednim od najvećih dostignuća naučne medicine svih vremena. Uprkos brojnim dokazima delotvornosti i bezbednosti, vakcinacija je kroz čitavu svoju istoriju bila praćena otporima i sumnjama. Oklevanje i odbijanje vakcinacije su u ovom veku ponovo u porastu, što je uzrokovano složenim spletom činilaca i okolnosti. Opadanje obuhvata dece vakcinacijom je u mnogim zemljama već dovelo do povratka prethodno eliminisanih oboljenja predupredivih vakcinacijom i nosi značajnu pretnju po narodno zdravlje. Pomenuto opadanje obuhvata tesno je povezano s uvećanim širenjem netačnih informacija o bezbednosti i delotvornosti vakcina, zajedno sa narastanjem antivakcinalnog aktivizma. To, između ostalog, podvlači potrebu za poboljšanjem komunikacije između zdravstvenih radnika i roditelja, kao i za obuhvatnijim pristupom podizanju nivoa pouzdanja u vakcine, pri čemu važne uloge pripadaju kako naučnicima i lekarima, tako i medijima i društvenoj zajednici. U ovom radu razmatramo fenomenologiju i kauzalnu strukturu oklevanja i odbijanja vakcinacije, uz kratak pregled nekih rasprostranjenih pitanja u vezi sa vakcinama, od značaja za svakodnevnu praksu.

Ključne reči: vakcinacija, deca, oklevanje u vezi s vakcinacijom, narodno zdravlje 